\title{
MORPHO-PHYSIOLOGICAL AND MOLECULAR RESPONSES OF COWPEA (VIGNA SINENSIS L.) TO NICKEL TOXICITY
}

\author{
AL-MUWAYHI, M. A. \\ Department of Physics and Chemistry, Faculty of Science, Shaqra University, P.O. Box 33, \\ Shaqra 11961, Kingdom of Saudi Arabia \\ (e-mail: malmuwayhi@su.edu.sa; phone: +966-11-6224-4118) \\ (Received $6^{\text {th }}$ Nov 2020; accepted $8^{\text {th }}$ Feb 2021)
}

\begin{abstract}
One of the environmental risks that threatens us is the toxicity of nickel $\left(\mathrm{Ni}^{2+}\right)$. Cowpea (Vigna sinensis L.) plants require it in trace amounts, while high concentrations of it influence their biochemical and physiological processes. In the current study, the effect of various concentrations of nickel $\left(100,200\right.$, and $300 \mathrm{mg} \mathrm{Ni}^{2+} / \mathrm{kg}$ soil) has been investigated to identify their effects on Vigna sinensis. The results revealed the negative effects of nickel on most of the studied physiological and morphological traits compared with those of the control. The concentrations of mineral elements and chlorophyll decreased significantly. Reducing, non-reducing and total sugar content were affected negatively. Furthermore, the activity of studied enzymes (APX, GPX, CAT, SOD) decreased significantly. Moreover, the negative effects of nickel concentrations on the root, stem, leaves, seeds, flowers and fruits were obvious. On a molecular level, the ISSR markers could not detect any polymorphism, indicating no toxic effect of nickel on the DNA at the studied concentrations. It is obvious that the nickel has a toxic effect on Vigna sinensis at physiological and morphological levels. The conduction of more investigations on the effects of nickel on a molecular level using more molecular markers is highly recommended.
\end{abstract}

Keywords: enzyme, lipid, reducing sugar, protein, DNA, ISSR

\section{Introduction}

Cowpea (Vigna sinensis L.) is a very important leguminous plant throughout the world especially in rural areas, as it is a good source of protein and energy (Granito et al., 2005). There are many environmental hazards surrounding living organisms that pose a major risk to their life, safety and health, including heavy environmental hazards (Panda and Panda, 2002). The toxicity of heavy metals is one of the current major environmental health problems and is potentially dangerous due to their bioaccumulation through the food chain and in plant products that are used for human consumption. Therefore, soil and plant pollution with heavy metals has become an increasing problem (Kaveriammal and Subramani, 2013), as the important biological processes in the plant are greatly affected by the increase in the percentage of heavy metals such as the metabolism process and, consequently, the plant traits and yield (Sinha and Gupta, 2005). Increased levels of heavy metals in the plant may lead to food poisoning (Macnair, 1993). Nickel is considered one of the important and abundant elements in the earth's crust. It is one of the basic mineral nutrients found in natural soil with minimal concentrations (Hussain et al., 2013). It is one of the important heavy metals in the environment, which gains wide recognition and is also essential for plants (Harasim and Filipek, 2015). It is also one of the essential nutrients needed by the plant and there are many studies suggesting its importance and that it has beneficial effects for the plant at low concentration (Sabir et al., 2011; Rathor et al., 2014). Despite the primary role of the nickel in the plant, toxicologists considered that the toxicity of nickel poses an environmental threat to biological systems when these are overexposed to it. For instance: the study of Asagba et al. (2019) conducted on Vigna unguiculate L. indicated that there are significant 
differences when treating the soil with a concentration of $100 \mathrm{ppm}$ of nickel with adverse effects on plant height, plant growth rate and leaf $\mathrm{Ca}^{2+}$ ATPase activity. The main reasons for the high levels of nickel pollution in the environment are industrial and agricultural activities. To understand the role and importance of nickel for plants, it is necessary to understand the functional properties and toxic effects of nickel. The amount of nickel the plant needs for natural growth and development is very small, however it is considered an important component of the different enzymes in plants and a regulator of specific enzyme activities that are involved in maintaining the appropriate cellular oxidation state and many of the biochemical and physiological responses such as photosynthesis, plant pigments, cell membranes and other growth processes. High concentrations of nickel affect the morphological traits of the plant and prevent root growth (Hussain et al., 2013). There are many sources of nickel in the environment that may cause a problem if the nickel element is present in high concentrations because it is toxic to plants and other organisms (Harasim and Filipek, 2015). A study of Jagetiya and Bhatt (2007) conducted on cowpea (Vigna unguiculata L.) indicated that high concentrations $(1000 \mu \mathrm{m})$ of nickel led to a decrease in fresh mass, dry matter production and chlorophyll contents of seedlings. The treatment of cowpea (Vigna unguiculate L.) with high concentrations (1.8 $\mathrm{mM}$ and $2.4 \mathrm{Mm}$ ) of nickel led to a significant impact on the performance of seedlings growth and the effect on physiological and biochemical characteristics. Moreover, the concentration of $1.2 \mathrm{mM}$ affected negatively the number of leaves, length of seedlings, fresh weight, and dry weight of seedlings. Furthermore, concentrations of $0.6 \mathrm{mM}, 1.2$ $\mathrm{mM}, 1.8 \mathrm{mM}$ and $2.4 \mathrm{mM}$ showed less influence on leaf area, leaf weight ratio, root fresh and dry weight, while having a significant effect on the relative water content and chlorophyll A, B, and total chlorophyll, carotenoids and phenols (Mujeeb et al., 2019). Rathor et al. (2014) reported that high concentrations of nickel negatively affected maize plant. They showed that the dry matter decreased at the concentration of $50 \mathrm{mg} / \mathrm{kg}$. The results of many studies confirmed that the high concentrations of nickel become toxic to most plant species, as it affects the processes of photosynthesis, respiration, mineral nutrition, water relations, transport of mineral, and induction of oxidative stress (Llamas and Sanz, 2008; Llamas et al., 2008). The increase in the rates of accumulation of heavy metals also leads to a significant change in the genes of the organism and thus affects the genetic diversity (Panda and Panda, 2002). The toxicity of nickel caused clastogenicity and the aneugenicity in onion (Alium cepa) (Dovgalyuk et al., 2001). Scientists have been able to link and produce genetic maps using molecular markers such as AFLP, RAPD, RFLP, SSR. The development of genetic maps using molecular markers is one of the most important steps in the genome studies of plants (Ma et al., 2001; Nguyen et al., 2001). Al-Qurainy (2009) in his study on the molecular detection of Al and Ni toxicity on the Phaseolus vulgaris plant, concluded that the toxicity of heavy metals in plants is due to the stimulation of oxidative stress associated with oxidation of proteins and membranous fats and changes in the DNA damage response. The genetic toxicity induced by these minerals was evaluated using RAPD and this technique was useful in assessing the genetic toxicity. Moreover, a genetic mutation at a concentration of $150 \mathrm{mg} \mathrm{Ni} / \mathrm{kg}$ of soil was detected. The genetic toxicity of nickel was also assessed with RAPD molecular marker in a study on Barbados nut (Jatropha curcas) plants (Sarkar et al., 2010). RAPD analysis produced only 5 polymorphic bands (3.225\%) out of a total of 155 bands from 18 selected primers. Only three primers OPK-19, OPP-2, OPN-08 produced polymorphic bands. Gjorgieva et al. (2013) analyzed the biological effects induced by bioaccumulation of metals in common bean (Phaseolus vulgaris L.). Their results 
suggested that mineral nutrient imbalance is involved in changes of antioxidant levels and DNA damages of the seedlings, which may help to understand the mechanism of metal toxicity in plants. DNA polymorphism detected by ISSR analysis offered a useful molecular marker for the identification of mutants in gamma radiation-treated plants and demonstrated that the DNA of the hybrid "Doi Tung 554" of siam tulip (Curcuma alismatifolia) showed a greater response in induced mutation compared with the other varieties (Taheri et al., 2013). Al-Qurainy (2010) utilized ISSR molecular markers to study the effect of toxicity of three heavy metals $(\mathrm{Zn}, \mathrm{Pb}$, and $\mathrm{Cd}$ ) on DNA in the Eruca sativa L. plant, where 20 ISSR primers were used. The ranking of genotoxic potencies of the three heavy metals was in the descending order of $\mathrm{Cd}^{2+}>\mathrm{Pb}^{2+}>\mathrm{Zn}^{2+}$. Among these heavy metals, high concentration of $\mathrm{Cd}(150 \mathrm{mg} / \mathrm{l})$ and $\mathrm{Pb}(150 \mathrm{mg} / \mathrm{l})$ generated mutations along with changed morphology of seedlings. Despite the importance of nickel-polluted soils throughout the world, little is known about the activity of nickel required to reduce plant growth and the effects that nickel toxicity has on the plant. The aim of this study is to identify the toxic effects of nickel on physiological, morphological and molecular traits using ISSR molecular markers in Vigna sinensis L.

\section{Materials and methods}

\section{Plant material and experimentation}

The seeds of "Buff" variety of Vigna sinensis were purchased from the local market and the experiment was conducted at the Department of Chemistry, Faculty of Science, Shaqra University, Kingdom of Saudi Arabia. Three seeds were planted in each plastic pot containing $1 \mathrm{~kg}$ of sterilized soil. The concentrations of $\mathrm{Ni}\left(\mathrm{NiSO}_{4}\right)$ used for soil treatment were; $100 \mathrm{mg} / \mathrm{kg}$ soil, $200 \mathrm{mg} / \mathrm{kg}$ soil, $300 \mathrm{mg} / \mathrm{kg}$ soil, and the control. There were three replicates for all treatments. Plants were grown in a controlled air conditioned climate and light of green house $\left(24^{\circ} \mathrm{C}\right.$ and $13: 11$ hours dark-light cycle). Three plants from each replicate were sampled after 90 days of sowing (fruiting phenophase) and the targeted measurements were taken.

\section{Physiological parameters}

Phosphorous content was determined according to Murphy and Riley (1962). Potassium was determined using the Flame photometer according to Allen et al. (1989). Estimation of $\mathrm{Ca}$ and $\mathrm{Mg}$ were performed using the Atomic Absorption Spectroscopy instrument according to Stewart (Allen et al., 1974). Chlorophyll A, B and total were estimated using Metzner et al. (1965) method. Estimating non-reducing sugars was calculated by subtracting the value of reduced sugars from the value of total sugars. Determination of total sugars was done depending on Hedge et al. (1962). Reduced Sugars were estimated according to Li et al. (2013). Estimation of lipids was performed using the Soxhlet method. Total protein was estimated based on the nitrogen content of the sample using the Kjeldahl method (Jones Jr et al., 1991). Soluble protein was determined according to Bradford (1976). Superoxide dismutase (SOD) activity was estimated according to Giannopolitis and Ries (1977). Catalytic Activity (CAT) was estimated according to Aebi (1984). Guaiacol peroxidase (GPX) enzyme activity was estimated according to Egley et al. (1983). Ascorbate peroxidase (APX) enzyme activity was estimated according to Asada (1984). 


\section{Genomic DNA isolation}

\section{Reagents and chemicals}

The stock solution concentrations were: acetyl trimethyl ammonium bromide (CTAB) 3\% (w/v), $1 \mathrm{M}$ TrisCl (pH 8), 0.5 M EDTA (pH 8), $5 \mathrm{M} \mathrm{NaCl}$, absolute ethanol (AR grade). The extraction buffer consisted of CTA B 3\% (w/v), $100 \mathrm{mM}$ Tris $-\mathrm{Cl}(\mathrm{pH} 8)$, $25 \mathrm{mM}$ EDTA ( $\mathrm{pH} 8$ ), and $2 \mathrm{M} \mathrm{NaCl}$, respectively. The PVP and $\beta$-mercaptoethanol were freshly prepared and added in the extraction buffer.

\section{DNA extraction}

DNA was isolated from plants grown in green house using a modified CTAB method (Khan et al., 2007). In brief, the plant samples were ground into extraction buffer (100 mM tris buffer $\mathrm{pH} 8,25 \mathrm{mM}$ EDTA, $2 \mathrm{M} \mathrm{NaCl}, 3 \%$ CTAB, 3\% PVP). The suspension was gently mixed and incubated at $65^{\circ} \mathrm{C}$ for $20 \mathrm{~min}$ with occasional mixing. The suspension was then cooled to room temperature and an equal volume of chloroform: isoamyl alcohol (24:1) was added. The mixture was centrifuged at 12,000 rpm for $5 \mathrm{~min}$. The clear upper aqueous phase was then transferred to a new tube and $2 / 3$ volume of icecooled isopropanol was added followed by incubation at $-20^{\circ} \mathrm{C}$ for $30 \mathrm{~min}$. The nucleic acid was collected by centrifugation at $10,000 \mathrm{rpm}$ for $10 \mathrm{~min}$. The resulting pellet was washed twice with $80 \%$ ethanol. The pellet was air-dried under a sterile laminar hood and the nucleic acid was dissolved in TE (10 $\mathrm{mM}$ tris buffer $\mathrm{pH} 8,1 \mathrm{mM}$ EDTA) at room temperature and stored at $4^{\circ} \mathrm{C}$ until used. The RNA from crude DNA was eliminated by treating the sample with RNase $\mathrm{A}(10 \mathrm{mg} / \mathrm{ml})$ for $30 \mathrm{~min}$ at $37^{\circ} \mathrm{C}$. DNA concentration and purity were determined by measuring the absorbance of diluted DNA solution at 260 and $280 \mathrm{~nm}$. The quality of the DNA was determined using agarose gel electrophoresis stained with ethidium bromide.

\section{PCR amplification and ISSR reaction}

PCR amplification was done with ISSR primers according to the protocol developed by Zietkiewicz et al. (1994). Ten ISSR primers synthesized from Sigma Company were used to amplify the genomic DNA extracted from untreated and treated plants. After screening of the primers, two of them were promised to produce mono/polymorphism (Table 1).

Table 1. List of ISSR Primers used in the study

\begin{tabular}{c|c|c}
\hline Sequence & Code & Annealing temperature \\
\hline 5'-ACACACACACACACACC-3' & UBC-26 & $52.4^{\circ} \mathrm{C}$ \\
5'-AGAGAGAGAGAGAGAGYC-3' & UBC-35 & $53.9^{\circ} \mathrm{C}$ \\
\hline
\end{tabular}

The PCR reaction was carried out in $20 \mathrm{ml}$ volume of master mixture purchased from Amerson Company (UK). In master mixture, $30 \mathrm{ng}$ of template DNA and $30 \mathrm{ng}$ of primer were added in each tube. Tubes were vortexed and briefly centrifuged after adding template DNA and primer in master mixture. The amplification was done on 96 well plates on a Primus PCR machine as per the program: First denaturation at $94^{\circ} \mathrm{C}$ for $3 \mathrm{~min}$, segment denaturation at $94^{\circ} \mathrm{C}$ for $1 \mathrm{~min}$, annealing at $45^{\circ} \mathrm{C}$ for $30 \mathrm{~s}$, extension at $72^{\circ} \mathrm{C}$ for $1 \mathrm{~min}$ and final extension at $72^{\circ} \mathrm{C}$ for 3 min was performed for amplification. 


\section{Statistical analysis}

Completely Randomized Design was used (Stell et al., 1980). Analysis of variance was performed on the collected data using SAS 9.1, SAS Inc., North Carolina, USA (SAS, 2014). Thus, mean values were rated significant at $\mathrm{p}<0.05$. The least significant difference (LSD) test was used to discern differences among the mean values of the treatments and accessions.

\section{Results}

\section{Effect of nickel on the content of mineral elements in the leaves}

The results showed that there is an effect of different concentrations of nickel on phosphorous (P) content in the leaves of Vigna sinensis (Table 2). Generally, there were significant differences between all treatments compared to the control, however, there were no significant differences between the two concentrations ( 200 and $300 \mathrm{mg} / \mathrm{Kg}$ of soil). The results also showed that there is an effect of different concentrations of nickel on the potassium $(\mathrm{K})$ content of the leaves of Vigna sinensis. The differences were significant at all concentrations of nickel $(100,200,300 \mathrm{mg} / \mathrm{kg}$ of soil). The results also showed a negative effect of different concentrations of nickel on the Ca content of the leaves of the Vigna sinensis. There were significant differences between the concentration of $100 \mathrm{mg} / \mathrm{kg}$ of soil and the other concentrations $(200,300 \mathrm{mg} / \mathrm{kg}$ of soil), but no significant differences between the two concentrations (200 and $300 \mathrm{mg} / \mathrm{kg}$ of soil). The content of the leaves of Ca treated at concentration of $100 \mathrm{mg} / \mathrm{kg}$ of soil reached $16.6 \mathrm{ppm}$, and the lowest content was at $300 \mathrm{mg} / \mathrm{kg}$ of soil (13.3 ppm). The results also showed that there is an effect of the different concentrations of nickel on the content of magnesium (Mg) in the leaves of Vigna sinensis. There were significant differences at the all concentrations.

Table 2. Effect of various concentrations of nickel on the mineral elements in the leaves of Vigna sinensis

\begin{tabular}{c|c|c|c|c}
\hline $\begin{array}{c}\text { Treatments } \\
(\mathbf{m g} / \mathbf{k g} \text { soil })\end{array}$ & $\begin{array}{c}\mathbf{P} \\
(\mathbf{p p m})\end{array}$ & $\begin{array}{c}\mathbf{K} \\
(\mathbf{p p m})\end{array}$ & $\begin{array}{c}\mathbf{C a} \\
(\mathbf{p p m})\end{array}$ & $\begin{array}{c}\mathbf{M g} \\
(\mathbf{p p m})\end{array}$ \\
\hline Control & $2.2 \mathrm{a} \pm 0.6$ & $103.4 \mathrm{a} \pm 8.1$ & $21.2 \mathrm{a} \pm 13.3$ & $37.1 \mathrm{a} \pm 3.4$ \\
100 & $1.8 \mathrm{c} \pm 0.4$ & $94.3 \mathrm{~b} \pm 8.4$ & $16.6 \mathrm{~b} \pm 15.2$ & $22.3 \mathrm{~b} \pm 7.2$ \\
200 & $1.6 \mathrm{~b} \pm 0.9$ & $76.7 \mathrm{c} \pm 11.9$ & $14.2 \mathrm{c} \pm 7.8$ & $19.0 \mathrm{c} \pm 6.5$ \\
300 & $1.6 \mathrm{~b} \pm 0.8$ & $58.7 \mathrm{~d} \pm 13.6$ & $13.3 \mathrm{c} \pm 10.3$ & $15.3 \mathrm{~d} \pm 11.6$ \\
LSD 0.05 & 0.3 & 5.2 & 2.5 & 2.4 \\
\hline
\end{tabular}

Values are mean \pm SD for three replicates in each treatment. Within the same column, means followed by the same letter do not differ significantly $(\mathrm{p}<0.05)$

\section{Effect of nickel on the content of plant pigments in the leaves}

The results shown in Table 3. showed that there is an effect of different concentrations of nickel on the chlorophyll a in the leaves of the Vigna sinensis. There were significant differences between concentration $100 \mathrm{mg} / \mathrm{kg}$ of soil and concentrations 200 and $300 \mathrm{mg}$ / $\mathrm{kg}$ of soil, whereas no significant differences can be observed at the last two concentrations. It was observed that the concentration of chlorophyll a decreased as the 
toxicity of the nickel increased, compared to the control. The concentration of chlorophyll a in the plants exposed to a concentration of $100 \mathrm{mg} / \mathrm{kg}$ of soil is higher than the other concentrations of nickel. There is also an effect of different concentrations of nickel on the content of chlorophyll $\mathrm{b}$ in the leaves of Vigna sinensis.

Table 3. Effect of various concentrations of nickel on plant pigment concentration in Vigna sinensis L. leaves

\begin{tabular}{c|c|c|c}
\hline $\begin{array}{c}\text { Treatments } \\
(\mathbf{m g} / \mathbf{g})\end{array}$ & $\begin{array}{c}\text { Chlorophyll a } \\
(\boldsymbol{\mu g} / \mathbf{g})\end{array}$ & $\begin{array}{c}\text { Chlorophyll b } \\
(\boldsymbol{\mu g} / \mathbf{g})\end{array}$ & $\begin{array}{c}\text { Carotenoids } \\
(\boldsymbol{\mu g} / \mathbf{k g} \text { soil })\end{array}$ \\
\hline Control & $0.68 \mathrm{a} \pm 0.15$ & $0.41 \mathrm{a} \pm 0.12$ & $0.029 \mathrm{a} \pm 0.01$ \\
100 & $0.41 \mathrm{~b} \pm 0.15$ & $0.23 \mathrm{~b} \pm 0.07$ & $0.026 \mathrm{a} \pm 0.01$ \\
200 & $0.24 \mathrm{c} \pm 0.15$ & $0.26 \mathrm{~b} \pm 0.11$ & $0.031 \mathrm{a} \pm 0.02$ \\
300 & $0.23 \mathrm{c} \pm 0.17$ & $0.18 \mathrm{c} \pm 0.09$ & $0.027 \mathrm{a} \pm 0.02$ \\
LSD 0.05 & 0.05 & 0.04 & - \\
\hline
\end{tabular}

Values are mean \pm SD for three replicates in each treatment. Within the same column, means followed by the same letter do not differ significantly $(\mathrm{p}<0.05)$

\section{Effect of nickel on the sugar content in the leaves}

The results showed that there is an effect of the different concentrations of nickel on the content of reducing sugars in the leaves of the Vigna sinensis (Table 4). There were significant differences between the concentration of $100 \mathrm{mg} / \mathrm{kg}$ of soil and the other concentrations ( 200 and $300 \mathrm{mg} / \mathrm{kg}$ of soil). It was observed that there is decrement in the concentration of reducing sugars as the toxicity of the nickel increases compared to the control. In terms of non-reducing sugars, there were significant differences between the concentration of $100 \mathrm{mg} / \mathrm{kg}$ of soil and other two concentrations (200 and $300 \mathrm{mg} / \mathrm{kg}$ of soil). No significant differences were detected between the two concentrations of 200 and $300 \mathrm{mg} / \mathrm{kg}$ of soil. The results indicate that the content of nonreducing sugars in the plants exposed to concentration of $100 \mathrm{mg} / \mathrm{kg}$ of soil was the highest. Total sugars in the leaves of the Vigna sinensis L. also were affected negatively as the plants were exposed to different concentration of nickel. The content of total sugars at a concentration of $100 \mathrm{mg} / \mathrm{kg}$ of soil was higher than the other two concentrations (200 and $300 \mathrm{mg} / \mathrm{kg}$ of soil) with significant difference.

Table 4. Effect of various concentrations of nickel on sugar concentration in Vigna sinensis leaves

\begin{tabular}{c|c|c|c}
\hline $\begin{array}{c}\text { Treatments } \\
(\mathbf{m g} / \mathbf{k g} \text { soil) }\end{array}$ & $\begin{array}{c}\text { Reducing sugars } \\
(\mathbf{m g} / \mathbf{g})\end{array}$ & $\begin{array}{c}\text { Non-reducing sugars } \\
(\mathbf{m g} / \mathbf{g})\end{array}$ & $\begin{array}{c}\text { Total sugars } \\
(\mathbf{m g} / \mathbf{g})\end{array}$ \\
\hline Control & $49.2 \mathrm{a} \pm 15.1$ & $115.4 \mathrm{a} \pm 17.5$ & $164.6 \mathrm{a} \pm 34.1$ \\
100 & $30.7 \mathrm{~b} \pm 11.2$ & $112.2 \mathrm{~b} \pm 23.7$ & $142.9 \mathrm{~b} \pm 50.4$ \\
200 & $24.5 \mathrm{c} \pm 3.8$ & $97.1 \mathrm{c} \pm 41.4$ & $121.6 \mathrm{c} \pm 50.1$ \\
300 & $23.4 \mathrm{c} \pm 3.1$ & $99.4 \mathrm{c} \pm 45.9$ & $122.8 \mathrm{c} \pm 51.2$ \\
LSD 0.05 & 3.5 & 7.4 & 6.3 \\
\hline
\end{tabular}

Values are mean \pm SD for three replicates in each treatment. Within the same column, means followed by the same letter do not differ significantly $(\mathrm{p}<0.05)$ 


\section{Effect of nickel on lipids, total protein and soluble protein in the leaves}

The results revealed that there is an effect of the different concentrations of nickel on the content of lipids in the leaves of Vigna sinensis (Table 5). There were significant differences between the concentration of $100 \mathrm{mg} / \mathrm{kg}$ of soil and the other concentrations, but these differences were not significant between the concentrations of 200, and $300 \mathrm{mg} / \mathrm{kg}$ of soil. Total protein was negatively affected as a result of exposing the plants to different concentrations of nickel. There were significant differences between all concentrations. The total protein in the plants treated with a concentration of $100 \mathrm{mg} / \mathrm{kg}$ of soil was higher than at other concentrations. The results indicated that there is an effect of different concentrations of nickel on the soluble protein in the leaves. There are significant differences between concentration of $100 \mathrm{mg} / \mathrm{kg}$ of soil and other concentrations, but not the two concentrations of 200 and $300 \mathrm{mg} / \mathrm{kg}$ of soil. The soluble protein in plants treated with concentration of $100 \mathrm{mg} / \mathrm{kg}$ of soil was higher than that at other concentrations $(200,300 \mathrm{mg} / \mathrm{kg}$ of soil).

Table 5. Effect of various concentrations of nickel on lipids, total protein and soluble protein in Vigna sinensis leaf

\begin{tabular}{c|c|c|c}
\hline $\begin{array}{c}\text { Treatments } \\
(\mathbf{m g} / \mathbf{k g} \text { soil) }\end{array}$ & $\begin{array}{c}\text { Lipids } \\
(\boldsymbol{\%})\end{array}$ & $\begin{array}{c}\text { Total protein } \\
(\boldsymbol{\%})\end{array}$ & $\begin{array}{c}\text { Soluble protein } \\
(\mathbf{m g} / \mathbf{g})\end{array}$ \\
\hline Control & $4.43 \mathrm{a} \pm 1.65$ & $19.4 \mathrm{a} \pm 3.1$ & $9.2 \mathrm{a} \pm 0.11$ \\
100 & $4.12 \mathrm{a} \pm 1.15$ & $16.2 \mathrm{~b} \pm 3.7$ & $9.1 \mathrm{~b} \pm 0.12$ \\
200 & $2.21 \mathrm{~b} \pm 0.55$ & $12.4 \mathrm{c} \pm 6.2$ & $8.9 \mathrm{c} \pm 0.16$ \\
300 & $1.94 \mathrm{~b} \pm 0.47$ & $11.0 \mathrm{~d} \pm 4.0$ & $8.5 \mathrm{~d} \pm 0.08$ \\
LSD 0.05 & 0.25 & 0.973 & 0.07 \\
\hline
\end{tabular}

Values are mean \pm SD for three replicates in each treatment. Within the same column, means followed by the same letter do not differ significantly $(\mathrm{p}<0.05)$

\section{Effect of nickel on the activity of enzymes in the leaves}

The results showed that there is an effect of different concentrations of nickel on the activity of Ascorbate peroxidase (APX) in the leaves of the Vigna sinensis compared with the control (Table 6). However, no significant differences were detected between the three nickel concentrations (100, 200, and $300 \mathrm{mg} / \mathrm{kg}$ of soil). Guaiacol peroxidase (GPX) activity was decreased significantly as a result to exposing the plants to various nickel concentrations $(100,200$, and $300 \mathrm{mg} / \mathrm{kg}$ of soil). Oppositely, no significant differences were observed between nickel concentrations. There is a negative effect of nickel treatment on the activity of Catalase activity (CAT). It was observed that the general trend is a decrement in CAT activity as the toxicity of the nickel increases compared to the control. CAT activity in response to $100 \mathrm{mg} / \mathrm{kg}$ of soil was higher $(47.1 \mu \mathrm{mol} / \mathrm{min} /$ $\mathrm{mg}$ ) than that at other concentrations (200 and $300 \mathrm{mg} / \mathrm{kg}$ of soil). Superoxide dismutase (SOD) activity also significantly decreased in response to nickel treatments (100, 200 and $300 \mathrm{mg} / \mathrm{kg}$ of soil). The general trend is a decrement in the SOD activity as the toxicity of the nickel increases compared to the control. The results showed that the percentage of SOD activity in plants treated with a concentration of $100 \mathrm{mg} / \mathrm{kg}$ of soil is higher $(41.3$ $\mu \mathrm{mol} / \mathrm{min} / \mathrm{mg}$ ) than the concentrations of 200 and $300 \mathrm{mg} / \mathrm{kg}$ of soil (38.4 and 38.1 $\mu \mathrm{mol} / \mathrm{min} / \mathrm{mg}$ ), respectively. 
Table 6. Effect of various concentrations of nickel on the activity of enzymes in leaves of Vigna sinensis

\begin{tabular}{c|c|c|c|c}
\hline $\begin{array}{c}\text { Treatments } \\
(\mathbf{m g} / \mathbf{k g} \text { soil) }\end{array}$ & $\begin{array}{c}\text { Ascorbate } \\
\text { peroxidase(APX) } \\
(\boldsymbol{\mu} \mathbf{m o l} / \mathbf{m i n} / \mathbf{m g} \\
\mathbf{p r o t e i n})\end{array}$ & $\begin{array}{c}\text { Guaiacol } \\
\text { peroxidase }(\mathbf{G P X}) \\
(\boldsymbol{\mu m o l} / \mathbf{m i n} / \mathbf{m g} \\
\mathbf{p r o t e i n})\end{array}$ & $\begin{array}{c}\text { Catalase }(\mathbf{C A T}) \\
(\boldsymbol{\mu m o l} / \mathbf{m i n} / \mathbf{m g} \\
\mathbf{p r o t e i n})\end{array}$ & $\begin{array}{c}\text { Superoxide } \\
\mathbf{d i s m u t a s e}(\mathbf{S O D}) \\
(\boldsymbol{\mu m o l} / \mathbf{m i n} / \mathbf{m g} \\
\mathbf{p r o t e i n})\end{array}$ \\
\hline Control & $2.6 \mathrm{a} \pm 0.08$ & $2.15 \mathrm{a} \pm 0.04$ & $55.2 \mathrm{a} \pm 0.11$ & $47.2 \mathrm{a} \pm 2.34$ \\
100 & $1.3 \mathrm{~b} \pm 0.28$ & $2.08 \mathrm{~b} \pm 0.34$ & $47.1 \mathrm{~b} \pm 2.12$ & $41.3 \mathrm{~b} \pm 0.98$ \\
200 & $1.3 \mathrm{~b} \pm 0.06$ & $1.92 \mathrm{~b} \pm 0.08$ & $45.9 \mathrm{c} \pm 1.16$ & $38.4 \mathrm{c} \pm 4.28$ \\
300 & $1.2 \mathrm{~b} \pm 0.05$ & $1.91 \mathrm{~b} \pm 0.06$ & $39.5 \mathrm{c} \pm 4.18$ & $38.1 \mathrm{c} \pm 4.51$ \\
LSD 0.05 & 0.13 & 0.973 & 0.10 & 1.28 \\
\hline
\end{tabular}

Values are mean \pm SD for three replicates in each treatment. Within the same column, means followed by the same letter do not differ significantly $(\mathrm{p}<0.05)$

\section{Effect of nickel on plant height, leaf area, and number of leaves}

The results revealed that there is no significant effect of the different concentration of nickel $(100,200$, and $300 \mathrm{mg} / \mathrm{kg}$ of soil) on the plant height neither comparing with the control nor within the different concentrations. However, leaf area and number of leaves were significantly decreased as a result of exposing to the different concentrations of nickel $\left(100,200\right.$, and $300 \mathrm{mg} \mathrm{Ni}^{2+} / \mathrm{kg}$ of soil) compared with the control. Moreover, high significant differences between the nickel concentrations were detected as well (Table 7).

Table 7. Effect of various concentrations of nickel on plant height, leaf area, and number of leaves in Vigna sinensis

\begin{tabular}{c|c|c|c}
\hline $\begin{array}{c}\text { Treatments } \\
(\mathbf{m g} / \mathbf{k g} \text { soil) }\end{array}$ & $\begin{array}{c}\text { Plant height } \\
(\mathbf{c m})\end{array}$ & $\begin{array}{c}\text { Leaf area } \\
\left(\mathbf{c m}^{\mathbf{2}}\right)\end{array}$ & Number of leaves \\
\hline Control & $65.4 \mathrm{a} \pm 21.1$ & $959.4 \mathrm{a} \pm 366$ & $15.3 \mathrm{a} \pm 3.1$ \\
100 & $64.1 \mathrm{a} \pm 21.2$ & $798.2 \mathrm{~b} \pm 274$ & $11.1 \mathrm{~b} \pm 2.6$ \\
200 & $64.2 \mathrm{a} \pm 21.3$ & $756.3 \mathrm{c} \pm 267$ & $10.4 \mathrm{c} \pm 2.2$ \\
300 & $62.4 \mathrm{a} \pm 22.2$ & $746.4 \mathrm{~d} \pm 254$ & $10.1 \mathrm{~d} \pm 2.1$ \\
LSD 0.05 & 2.6 & 36.5 & 0.62 \\
\hline
\end{tabular}

Values are mean \pm SD for three replicates in each treatment. Within the same column, means followed by the same letter do not differ significantly $(\mathrm{p}<0.05)$

\section{Effect of nickel on the wet weight of plant parts}

The wet weight of the plant and all its parts (stem, leaf and root) were affected negatively in response to the different concentration of nickel $(100,200$, and $300 \mathrm{mg}$ $\mathrm{Ni}^{2+} / \mathrm{kg}$ of soil). The statistical analysis of the results revealed high significant differences between the nickel concentrations and the control, and within the concentrations as well (Table 8). The general trend indicates a decrement in the wet weight of the plant and all its part as increasing the toxicity of nickel. The average wet weight of the stem ranged from $142.4 \mathrm{~g}$ at a concentration of $100 \mathrm{mg} / \mathrm{kg}$ of soil to 51.4 $\mathrm{g}$ at a concentration of $300 \mathrm{mg} / \mathrm{kg}$ of soil. The average wet weight the root at a concentration of $100 \mathrm{mg} / \mathrm{kg}$ of soil was greater than at the concentrations of 200 and 300 $\mathrm{mg} / \mathrm{kg}$ of soil. It reached 32.2, 24.1, $23.4 \mathrm{~g}$, respectively. The average wet weight of the plant at a concentration of $300 \mathrm{mg} / \mathrm{kg}$ of soil was $106.6 \mathrm{~g}$. 
Table 8. Effect of various concentrations of nickel on stem wet weight, leaf wet weight, root wet weight, plant wet weight in Vigna sinensis

\begin{tabular}{c|c|c|c|c}
\hline $\begin{array}{c}\text { Treatments } \\
(\mathbf{m g} / \mathbf{k g} \text { soil) }\end{array}$ & $\begin{array}{c}\text { Stem wet weight } \\
(\mathbf{g})\end{array}$ & $\begin{array}{c}\text { Leaf wet weight } \\
(\mathbf{g})\end{array}$ & $\begin{array}{c}\text { Root wet weight } \\
(\mathbf{g})\end{array}$ & $\begin{array}{c}\text { Plant wet weight } \\
(\mathbf{g})\end{array}$ \\
\hline Control & $142.4 \mathrm{a} \pm 65.5$ & $126.4 \mathrm{a} \pm 45.1$ & $40.3 \mathrm{a} \pm 10.5$ & $309.1 \mathrm{a} \pm 124.1$ \\
100 & $109.2 \mathrm{~b} \pm 44.5$ & $86.2 \mathrm{~b} \pm 24.7$ & $32.2 \mathrm{~b} \pm 7.5$ & $227.6 \mathrm{~b} \pm 73.7$ \\
200 & $59.1 \mathrm{c} \pm 27.5$ & $42.1 \mathrm{c} \pm 8.2$ & $24.1 \mathrm{c} \pm 2.5$ & $125.3 \mathrm{c} \pm 36.2$ \\
300 & $51.4 \mathrm{~d} \pm 9.7$ & $31.8 \mathrm{~d} \pm 10.7$ & $23.4 \mathrm{~d} \pm 1.7$ & $106.6 \mathrm{~d} \pm 19.7$ \\
LSD 0.05 & 3.5 & 4.03 & 2.3 & 4.6 \\
\hline
\end{tabular}

Values are mean \pm SD for three replicates in each treatment. Within the same column, means followed by the same letter do not differ significantly $(\mathrm{p}<0.05)$

\section{Effect of nickel on the dry weight of plant parts}

The dry weight of the plant and all its parts (stem, leaf and root) were affected negatively in response to the different concentrations of nickel $(100,200$, and $300 \mathrm{mg}$ $\mathrm{Ni}^{2+} / \mathrm{kg}$ of soil). The statistical analysis of the results revealed high significant differences between the nickel concentrations and the control, and within the concentrations as well (Table 9). The general trend indicates a decrement in the dry weight of the plant and all its part as the toxicity of nickel increased. The average dry weight of the stem ranged from $22.2 \mathrm{~g}$ at a concentration of $100 \mathrm{mg} / \mathrm{kg}$ of soil to $13.4 \mathrm{~g}$ at a concentration of $300 \mathrm{mg} / \mathrm{kg}$ of soil). The dry weight of the leaf at a concentration of $100 \mathrm{mg} / \mathrm{kg}$ of soil was greater than at the other two concentrations $(200$ and $300 \mathrm{mg} / \mathrm{kg}$ of soil). It was $31.2,17.1$ and $14.4 \mathrm{~g}$, respectively. The average dry weight of the root ranged from $15.2 \mathrm{~g}$ at a concentration of $100 \mathrm{mg} / \mathrm{kg}$ of soil to $12.4 \mathrm{~g}$ at a concentration of $300 \mathrm{mg} / \mathrm{kg}$ of soil. The average of plant dry weight at a concentration of $100 \mathrm{mg} / \mathrm{kg}$ of soil was greater than at the concentrations of 200 and $300 \mathrm{mg} / \mathrm{kg}$ of soil. It reached $68.6,46.0$ and $40.2 \mathrm{~g}$, respectively.

Table 9. Effect of various concentrations of nickel on stem dry weight, leaf dry weight, root dry weight and plant dry weight in Vigna sinensis

\begin{tabular}{c|c|c|c|c}
\hline $\begin{array}{c}\text { Treatments } \\
(\mathrm{mg} / \mathrm{kg} \text { soil })\end{array}$ & $\begin{array}{c}\text { Stem dry weight } \\
(\mathrm{g})\end{array}$ & $\begin{array}{c}\text { Leaf dry weight } \\
(\mathrm{g})\end{array}$ & $\begin{array}{c}\text { Root dry weight } \\
(\mathrm{g})\end{array}$ & $\begin{array}{c}\text { Plant dry weight } \\
(\mathrm{g})\end{array}$ \\
\hline Control & $38.7 \mathrm{a} \pm 4.51$ & $44.3 \mathrm{a} \pm 9.14$ & $17.3 \mathrm{a} \pm 4.24$ & $100.3 \mathrm{a} \pm 13.24$ \\
100 & $22.2 \mathrm{~b} \pm 4.76$ & $31.2 \mathrm{~b} \pm 5.56$ & $15.2 \mathrm{~b} \pm 1.46$ & $68.6 \mathrm{~b} \pm 9.36$ \\
200 & $15.8 \mathrm{c} \pm 3.54$ & $17.1 \mathrm{c} \pm 2.54$ & $13.1 \mathrm{c} \pm 1.44$ & $46.0 \mathrm{c} \pm 6.24$ \\
300 & $13.4 \mathrm{~d} \pm 1.73$ & $14.4 \mathrm{~d} \pm 1.71$ & $12.4 \mathrm{~d} \pm 1.81$ & $40.2 \mathrm{~d} \pm 2.91$ \\
LSD 0.05 & 2.2 & 2.1 & 1.1 & 2.7 \\
\hline
\end{tabular}

Values are mean \pm SD for three replicates in each treatment. Within the same column, means followed by the same letter do not differ significantly $(\mathrm{p}<0.05)$

\section{Effect of nickel on the number of flowers and flower weight}

The results showed that there is an effect of the concentrations of nickel on the number of flowers. There are significant differences between the concentration of $100 \mathrm{mg} / \mathrm{kg}$ of soil and the concentrations of 200 and $300 \mathrm{mg} / \mathrm{kg}$ of soil, whereas there is no significant difference between the concentrations of 200 and $300 \mathrm{mg} / \mathrm{kg}$ of soil. The average number 
of flowers ranged from 18.2 at a concentration of $100 \mathrm{mg} / \mathrm{kg}$ of soil and 14.1 at a concentration of $300 \mathrm{mg} / \mathrm{kg}$ of soil (Table 10). The toxicity of nickel had an effect on the wet weight of flowers at all concentrations compared to the control. The results showed that there were significant differences between the concentration of $100 \mathrm{mg} / \mathrm{kg}$ of soil and the concentrations of $200,300 \mathrm{mg} / \mathrm{kg}$ of soil. The wet weight of flowers at concentrations of 100,200 , and $300 \mathrm{mg} / \mathrm{kg}$ of soil were $8.2,7.2$, and $7.0 \mathrm{~g}$, respectively. The average dry weight of flower at a concentration of $100 \mathrm{mg} / \mathrm{kg}$ of soil was greater than at concentrations of 200 and $300 \mathrm{mg} / \mathrm{kg}$ of soil with significant differences. It reached $0.52 \mathrm{~g}$ at a concentration of $100 \mathrm{mg} / \mathrm{kg}$ of soil and $0.42,0.35 \mathrm{~g}$ at concentrations of 200 and $300 \mathrm{mg} / \mathrm{Kg}$ of soil, respectively.

Table 10. Effect of various concentrations of nickel on number of flowers, flower wet weight, and flower dry weight in Vigna sinensis

\begin{tabular}{c|c|c|c}
\hline $\begin{array}{c}\text { Treatments } \\
(\mathbf{m g} / \mathbf{k g} \text { soil) }\end{array}$ & Number of flowers & $\begin{array}{c}\text { Flower wet weight } \\
(\mathbf{g})\end{array}$ & $\begin{array}{c}\text { Flower dry weight } \\
\mathbf{( g )}\end{array}$ \\
\hline Control & $42.3 \mathrm{a} \pm 3.5$ & $23.2 \mathrm{a} \pm 1.4$ & $1.1 \mathrm{a} \pm 0.11$ \\
100 & $18.2 \mathrm{c} \pm 1.3$ & $8.2 \mathrm{~b} \pm 0.6$ & $0.52 \mathrm{~b} \pm 0.01$ \\
200 & $15.1 \mathrm{~d} \pm 1.1$ & $7.2 \mathrm{c} \pm 0.3$ & $0.42 \mathrm{c} \pm 0.03$ \\
300 & $14.1 \mathrm{~d} \pm 0.1$ & $7.0 \mathrm{c} \pm 0.1$ & $0.35 \mathrm{~d} \pm 0.01$ \\
LSD 0.05 & 3.45 & 0.11 & 0.01 \\
\hline
\end{tabular}

Values are mean \pm SD for three replicates in each treatment. Within the same column, means followed by the same letter do not differ significantly $(\mathrm{p}<0.05)$

\section{Effect of nickel on the number of fruits and fruit wet and dry weight}

Treatment of the plants with different concentrations of nickel $(100,200$, and $300 \mathrm{mg} \mathrm{Ni}^{2+} / \mathrm{kg}$ of soil) affected number of fruits, fruit wet weight, and fruit dry weight in Vigna sinensis negatively. The statistical analysis reflected significant analysis between all the treatments compared with the control and among the concentrations of nickel (Table 11). The average number of fruits ranged from 10 at a concentration of $100 \mathrm{mg} / \mathrm{kg}$ of soil to 6.5 at a concentration of $300 \mathrm{mg} / \mathrm{kg}$ of soil. Average fruit wet weight at a concentration of $100 \mathrm{mg} / \mathrm{kg}$ of soil was greater than at the other two concentrations (200 and $300 \mathrm{mg} / \mathrm{kg}$ of soil). It was 12.2, 12.0, and $10.5 \mathrm{~g}$, respectively. The average fruit dry weight ranged from $1.7 \mathrm{~g}$ at a concentration of $100 \mathrm{mg} / \mathrm{kg}$ of soil to $1.2 \mathrm{~g}$ at a concentration of $300 \mathrm{mg} / \mathrm{kg}$ of soil.

Table 11. Effect of various concentrations of nickel on number of fruits, fruit wet weight, and fruit dry weight in Vigna sinensis

\begin{tabular}{c|c|c|c}
\hline $\begin{array}{c}\text { Treatments } \\
(\mathbf{m g} / \mathbf{k g} \text { soil) }\end{array}$ & Number of fruits & $\begin{array}{c}\text { Fruit wet weight } \\
(\mathbf{g})\end{array}$ & $\begin{array}{c}\text { Fruit dry weight } \\
(\mathbf{g})\end{array}$ \\
\hline Control & $17.6 \mathrm{a} \pm 2.5$ & $38.2 \mathrm{a} \pm 3.21$ & $5.6 \mathrm{a} \pm 0.70$ \\
100 & $10.1 \mathrm{~b} \pm 1.6$ & $12.2 \mathrm{~b} \pm 2.32$ & $1.7 \mathrm{~b} \pm 0.22$ \\
200 & $5.3 \mathrm{c} \pm 0.6$ & $12.0 \mathrm{c} \pm 2.03$ & $1.4 \mathrm{c} \pm 0.11$ \\
300 & $6.5 \mathrm{~d} \pm 1.2$ & $10.5 \mathrm{~d} \pm 1.71$ & $1.2 \mathrm{~d} \pm 0.10$ \\
LSD 0.05 & 3.1 & 6.11 & 0.8 \\
\hline
\end{tabular}

Values are mean \pm SD for three replicates in each treatment. Within the same column, means followed by the same letter do not differ significantly $(\mathrm{p}<0.05)$ 


\section{Effect of nickel on the number and weight of the seeds}

The results showed that there is an effect of different concentrations of nickel on the number of seeds in Vigna sinensis. As illustrated in Table 12, there were no significant differences between the three concentrations of nickel (100, 200, and $300 \mathrm{mg} / \mathrm{kg}$ of soil). The seed weight was also affected by nickel treatments. The general trend revealed a decrement in the average seed weight as the toxicity of nickel increases compared to the control.

Table 12. Effect of various concentrations of nickel on number of seeds, and seed weight in Vigna sinensis

\begin{tabular}{c|c|c}
\hline $\begin{array}{c}\text { Treatments } \\
(\mathbf{m g} / \text { kg soil) }\end{array}$ & Number of seeds & $\begin{array}{c}\text { Seed weight } \\
(\mathbf{g})\end{array}$ \\
\hline Control & $270.3 \mathrm{a} \pm 35.5$ & $36.4 \mathrm{a} \pm 6.1$ \\
100 & $60.1 \mathrm{~b} \pm 5.5$ & $8.1 \mathrm{~b} \pm 0.8$ \\
200 & $54.2 \mathrm{~b} \pm 6.5$ & $7.2 \mathrm{c} \pm 0.4$ \\
300 & $45.4 \mathrm{~b} \pm 2.7$ & $6.5 \mathrm{~d} \pm 0.5$ \\
LSD 0.05 & 32.5 & 5.4 \\
\hline
\end{tabular}

Values are mean \pm SD for three replicates in each treatment. Within the same column, means followed by the same letter do not differ significantly $(\mathrm{p}<0.05)$

\section{Effect of nickel on the flowering}

There is an effect of different concentrations of nickel on the beginning of flowering. There were significant differences between all treatments (Table 13). The general trend showed a delay in the flowering date as the toxicity of nickel increased compared with the control. The average flowering initiation period ranged from 55 days at a concentration of $100 \mathrm{mg} / \mathrm{kg}$ of soil to 56.4 days at a concentration of $300 \mathrm{mg} / \mathrm{kg}$ of soil. The effect of nickel toxicity on the end-flowering period was also observed in all concentrations compared to the control. As presented in Table 13, there were significant differences between the concentration of nickel (100, 200, and $300 \mathrm{mg} / \mathrm{kg}$ of soil). These results showed an effect of different concentrations of nickel on the flowering duration compared to the control. There are significant differences between the concentrations of 100,200 , and $300 \mathrm{mg} / \mathrm{kg}$ of soil. It was obvious that the average flowering duration decreased as the toxicity of nickel increased. It ranged from 40 days at a concentration of $100 \mathrm{mg} / \mathrm{kg}$ of soil to 37.9 days at a concentration of $300 \mathrm{mg} / \mathrm{kg}$ of soil.

Table 13. Effect of various concentrations of nickel on start flowering date, end flowering date, and flowering duration in Vigna sinensis

\begin{tabular}{c|c|c|c}
\hline $\begin{array}{c}\text { Treatments } \\
(\mathbf{m g} / \mathbf{k g} \text { soil) }\end{array}$ & $\begin{array}{c}\text { Start date of flowering } \\
\text { (day) }\end{array}$ & $\begin{array}{c}\text { End date of flowering } \\
\text { (day) }\end{array}$ & $\begin{array}{c}\text { Flowering duration } \\
\text { (day) }\end{array}$ \\
\hline Control & $50.2 \mathrm{c} \pm 0.0$ & $101.4 \mathrm{a} \pm 0.0$ & $51.2 \mathrm{a} \pm 0.0$ \\
100 & $55.2 \mathrm{~b} \pm 0.0$ & $95.2 \mathrm{~b} \pm 1.2$ & $40.0 \mathrm{~b} \pm 1.2$ \\
200 & $54.1 \mathrm{~b} \pm 1.0$ & $95.4 \mathrm{c} \pm 1.0$ & $41.3 \mathrm{c} \pm 1.7$ \\
300 & $56.4 \mathrm{a} \pm 0.6$ & $94.3 \mathrm{c} \pm 1.0$ & $37.9 \mathrm{~d} \pm 1.05$ \\
LSD 0.05 & 1.1 & 1.7 & 2.2 \\
\hline
\end{tabular}

Values are mean \pm SD for three replicates in each treatment. Within the same column, means followed by the same letter do not differ significantly $(\mathrm{p}<0.05)$ 


\section{Effect of nickel on the fruiting}

The results showed that there is negative effect of different concentrations of nickel on the beginning of fruiting. There are significant differences between the concentrations (Table 14). The average start of fruiting ranged from 76.2 days at a concentration of $100 \mathrm{mg} / \mathrm{kg}$ of soil to 80.2 days at a concentration of $300 \mathrm{mg} / \mathrm{kg}$ of soil. The effect of nickel toxicity on the end of fruiting date was observed in all concentrations compared to the control. Although there was a significant difference between all concentrations of nickel compared with the control, there were no significant differences between the concentrations. The results also showed an effect of different concentrations of nickel on the fruiting duration compared with the control. There were significant differences between the treatments. The average fruiting period ranged from 26.9 days at a concentration of 100 $\mathrm{mg} / \mathrm{Kg}$ of soil and 21.2 days at a concentration of $300 \mathrm{mg} / \mathrm{kg}$ of soil.

Table 14. Effect of various concentrations of nickel on start fruiting date, end fruiting date, and fruiting duration in Vigna sinensis

\begin{tabular}{c|c|c|c}
\hline $\begin{array}{c}\text { Treatments } \\
\text { (mg/kg soil) }\end{array}$ & $\begin{array}{c}\text { Start date of fruiting } \\
\text { (day) }\end{array}$ & $\begin{array}{c}\text { End date of fruiting } \\
\text { (day) }\end{array}$ & $\begin{array}{c}\text { Fruiting duration } \\
\text { (day) }\end{array}$ \\
\hline Control & $64.3 \mathrm{c} \pm 1.0$ & $110.4 \mathrm{a} \pm 1.2$ & $46.1 \mathrm{a} \pm 2.2$ \\
100 & $76.2 \mathrm{~b} \pm 1.2$ & $103.1 \mathrm{~b} \pm 1.5$ & $26.9 \mathrm{~b} \pm 1.9$ \\
200 & $77.1 \mathrm{~b} \pm 0.6$ & $102.3 \mathrm{~b} \pm 1.2$ & $25.2 \mathrm{c} \pm 0.7$ \\
300 & $80.2 \mathrm{a} \pm 0.0$ & $101.4 \mathrm{~b} \pm 1.7$ & $21.2 \mathrm{c} \pm 1.4$ \\
LSD 0.05 & 1.8 & 2.3 & 3.2 \\
\hline
\end{tabular}

Values are mean $\pm \mathrm{SD}$ for three replicates in each treatment $(\mathrm{p}<0.05)$

\section{Effect of nickel on the DNA}

Two ISSR responding primers which produced clear cut and reproducible bands (UBC 26 and UBC 35) were further used to amplify genomic DNA from all treated and untreated plants. The results revealed that all appeared fragments were monomorphic (Figures 1 and 2) and no differences were observed between the treatments. These results indicated that there is no genotoxic effect of nickel on the DNA of Vigna sinensis at the treatments of 100, 200, and $300 \mathrm{mg} / \mathrm{kg}$ soil.

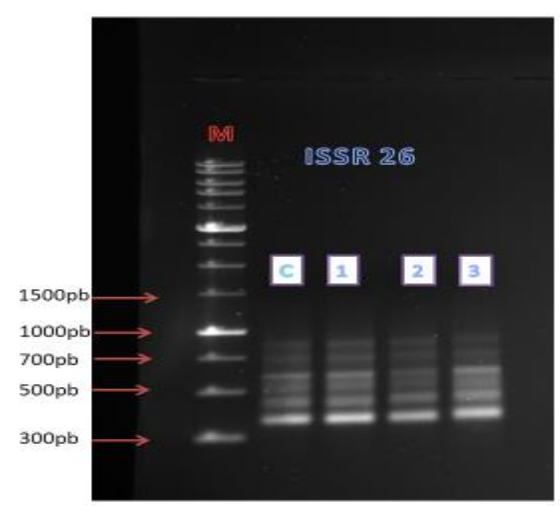

Figure 1. ISSR fingerprints for Vigna sinensis treated with various concentrations of nickel with primer UBC 26. Lane M: 1 kb DNA ladder; Lane c: control; Lanes 1, 2, 3: plants treated with nickel at concentrations of 100, 200 and $300 \mathrm{mg} / \mathrm{kg}$ soil, respectively 


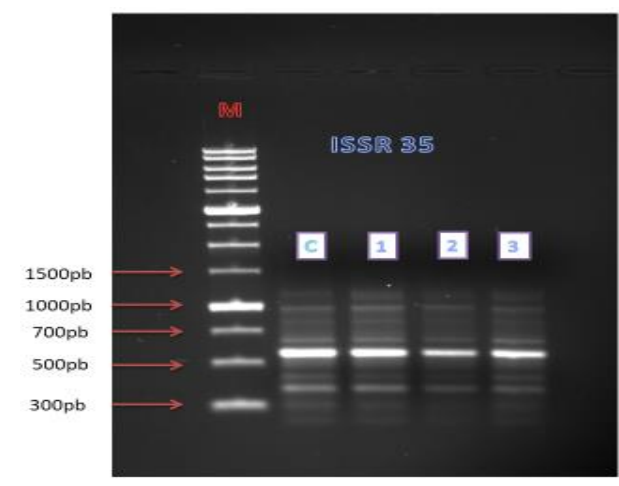

Figure 2. ISSR fingerprints for Vigna sinensis treated with various concentrations of nickel with primer UBC 35. Lane M: 1 kb DNA ladder; Lane c: control; Lanes 1, 2, 3: plants treated with nickel at concentrations of 100, 200 and $300 \mathrm{mg} / \mathrm{kg}$ soil, respectively

\section{Discussion}

Nickel $\left(\mathrm{Ni}^{2+}\right)$ is one of the essential nutrients for plants, but it is toxic to plants at high concentrations. Plant species differ greatly in their ability to mineral absorption and accumulation, and these differences often help in the explanation of the plant's tolerance to mineral toxins (Yang et al., 1996). In this study, the toxic effects of nickel on physiological, morphological and molecular traits of cowpea (Vigna sinensis). were investigated. Three concentrations of nickel were used $(100,200$, and $300 \mathrm{mg} / \mathrm{kg}$ of soil). The results showed that the three nickel concentrations $(100,200,300 \mathrm{mg} / \mathrm{kg}$ of soil) affected the physiological traits negatively. It was observed that the $\mathrm{P}, \mathrm{K}, \mathrm{Mg}$, and Ca content of Vigna sinensis leaves decreased as the concentration of nickel increased compared with the control. These results are consistent with Harasim and Filipek (2015) who stated that nickel causes toxicity to the plant if it is present in high concentrations. However, it is inconsistent with the results of Piccini and Malavolta (1992) in their study on the bean plant (Phaseolus vulgaris L.). They found that when the concentration of nickel increased the levels of $\mathrm{N}, \mathrm{P}, \mathrm{K}$, and $\mathrm{Cu}$ elements increased. Whereas there were no significant changes in the concentrations of $\mathrm{Ca}, \mathrm{Mg}, \mathrm{Mn}$ and $\mathrm{Zn}$ in the plant tissues. The results also revealed that there is an effect of the three nickel concentrations $(100,200$, $300 \mathrm{mg} / \mathrm{kg}$ of soil) on the concentration of chlorophyll a \& b, and carotenoids in the Vigna sinensis L. plant. It was obvious that the general trend is a decrement in the concentration of chlorophyll $\mathrm{a}, \mathrm{b}$ and carotenoids as the concentration of the nickel increases compared with the control. This may be attributed to the fact that the exposure of the plant to the toxicity of nickel leads to a negative effect on the growth of chloroplasts, which leads to a noticeable effect in the process of chlorophyll synthesis as a result of reducing photosynthetic pigments. These results are in alignment with several studies. For instance: Piccini and Malavolta (1992), who found that the nickel toxicity had a significant impact on the reduction of chlorophyll in the bean leaf (Phaseolus vulgaris L.). Ewais (1997) who investigated the effect of heavy metals on the decrement of chlorophyll content in three herbaceous plants (Cyperus difformis, Chenopodium ambrosioides, and Digitaria sanguinalis). Kaveriammal and Subramani (2013) who studied the effect of nickel chloride $\left(\mathrm{NiCl}_{2}\right)$ on peanut (Arachis hypogeaea L.) and observed a negative effect of $\mathrm{NiCl}_{2}$ on chlorophyll a \& b, total chlorophyll, and carotenoids. Stanisavljevic et al. (2012) who investigated the effect of nickel on Alyssum markgrafii and found toxic effects of nickel on chlorophyll a \& b, total chlorophyll, and 
carotenoids. Singh and Pandey (2011) who investigated the nickel toxicity on chlorophyll a \& b in Pistia stratiotes. Hussain et al. (2013) who concluded that nickel inhibits the activity of plant pigments. The results indicated that the sugar content (reducing, nonreducing and total sugars) of Vigna sinensis leaves were affected negatively by the toxicity of nickel at all studied concentrations $(100,200$, and $300 \mathrm{mg} / \mathrm{kg}$ of soil) compared with the control. The reason behind may be due to the accumulation of nickel in the leaves and to the small leaf area where the sugars are manufactured. These results are in parallel with what was indicated by Ashraf et al. (2011) in their experiments on sunflower (Helianthus annuus L.). They observed that treatment of the plant with various levels of nickel led to a disturbance in the metabolism of the chemical and, consequently, affected the availability of sugars that produce metabolic energy due to the toxicity of nickel. Our findings found that there is an effect of nickel various concentrations (100, 200 , and $300 \mathrm{mg} / \mathrm{kg}$ soil) on lipid ratio, total protein and soluble protein in the leaves of Vigna sinensis. They indicated the effect of nickel toxicity on the percentage of fat as the concentration of toxicity of nickel increased compared with the control. The ratio of total protein and soluble protein in the leaves was affected by the toxicity of nickel at high concentrations ( $300 \mathrm{mg} / \mathrm{kg}$ of soil) compared to the control, and this may be due to the accumulation of nickel in the leaves and the decrease in the dry matter of the vegetative and root parts of the plant, which negatively affected the protein content. These findings are consistent with Stanisavljević et al. (2012) who indicated that high concentrations of nickel lead to oxidation of fats in Alyssum markgrafii plants. The results of our study are also in alignment with those of Kumar et al. (2011) in their study on barley, where they observed a significant decrease in the protein thiol content of leaves. Several researchers also reported that the toxicity of nickel in the leaves of plants affects the physiological characteristics and works to decrease the contents of protein and fats (Ewais, 1997; Ashraf et al., 2011; Kumar et al., 2011; Singh and Pandey, 2011; Stanisavljević et al., 2012; Kaveriammal and Subramani, 2013). The results showed that nickel concentrations (100, $200,300 \mathrm{mg} / \mathrm{kg}$ of soil) negatively affected the antioxidant enzymes including Ascorbate peroxidase (APX), Catalase (CAT), Guaiacol peroxidase (GPX) Superoxide dismutase (SOD) in the leaves of Vigna sinensis. The activity ratio of all enzymes decreased at different treatments of nickel and the decrease was significant at a concentration of 300 $\mathrm{mg} / \mathrm{kg}$ of soil followed by the two concentrations (200 and100 mg / kg of soil). The reason may be attributed to the fact that the nickel toxicity has the ability to bind with the enzymes, which leads to changes in their potency and performance. These results are in parallel with Shahzad et al. (2018) who indicated that nickel is a toxic pollutant in agricultural environments and excessive concentration of nickel disrupts the nature of biological enzymes. It also agrees with the results of Ashraf et al. (2011) who noticed that the toxicity of nickel leads to a disturbance in the chemical metabolism in sunflower (Helianthus annuus L.). which leads to a shortage of amino acids necessary for the production of proteins and enzymes needed for fetal growth due to inhibition of activities of $\alpha$ - Amylase and protease. However, our results are in contrast with the results of Kumar et al. (2011), who observed a significant increase in the activities of Guaiacol peroxidase (GPX), Ascorbate peroxidase (APX) and Superoxide dismutase (SOD) and Glutathione reductase (GR) Catalase (CAT) when treating Barley malt plant with two concentrations of nickel $(200 \& 400 \mu \mathrm{M})$. The results of Maheshwari and Dubey (2009) in their conducted-on rice seedlings (Oryza sativa L.) showed an increase in the activity of guaiacol peroxidases (GPX) and ascorbate peroxidase (APX). Whereas our results agree with them in that the toxicity of nickel significantly reduces Glutathione reductase 
(GR) enzyme in the treated seedlings. Our results also showed that there is an effect of nickel various concentrations $(100,200,300 \mathrm{mg} / \mathrm{kg}$ of soil) on the morphological traits of Vigna sinensis. Stem length, leaf area, and number of leaves decreased in response to high toxic concentration of nickel (300 mg / Kg of soil) compared with the control. This may be due to the fact that the nickel toxicity affects the processes of cell division, and thus this affects vegetative growth and the dry and fresh weight of the plant. The nickel toxicity might lead to the disruption of metabolic processes such as photosynthesis, respiration, protein synthesis, enzyme activity and other processes that lead to a decline in plant growth and yield. These results are in alignment with many findings of previous researchers who noticed the symptoms of nickel toxicity that resulted in a decrease in the average plant height, leaf area, and necrosis of the leaves (Piccini and Malavolta, 1992; Yadav and Aery, 2001; Al-Qurainy, 2009; Maheshwari and Dubey, 2009; Kumar et al., 2011; Singh and Pandey, 2011; Hussain et al., 2013; Kaveriammal and Subramani, 2013). However, these results are inconsistent with Asagba et al. (2019) who noticed that there are no significant changes in the plant height and growth rate when the plants were exposed to low concentrations of nickel. The results of the current study indicated that there is an effect of nickel concentrations $(100,200$, and $300 \mathrm{mg} / \mathrm{kg}$ of soil) on the decrement of root weight and total plant weight. This decrease was significant at concentration of $300 \mathrm{mg} / \mathrm{kg}$ of soil compared with the two concentrations (200 \&100 $\mathrm{mg} / \mathrm{kg}$ of soil). This indicates that high concentrations of nickel affect the processes of cell division and thus this affects the weight of fresh and dry plants and the roots. The results of our study are in agreement with many previous studies which indicated that the exposure of the plant to the toxicity of nickel in high concentrations resulted in affecting the plant weight, root growth and length, and reducing fresh and dry weight and the length of the root tip (Yadav and Aery, 2001; Al-Qurainy, 2009; Maheshwari and Dubey, 2009; Kumar et al., 2011; Hussain et al., 2013; Kaveriammal and Subramani, 2013; Rathor et al., 2014). However, the results are in contrast with the findings of Asagba et al. (2019) who reported no significant changes in fresh weight and growth rate when the plant was treated with low concentrations of nickel. Regarding the seeds, results indicated that there was a negative effect for nickel treatments on the number of seeds and seed weight. This effect was increased by increasing concentrations of nickel $(100,200$, and $300 \mathrm{mg} / \mathrm{kg}$ of soil). These results are in alignment with the findings of Yadav and Aery (2001) who reported that the toxicity of high concentrations of nickel affects seed production. Whereas it does not agree with the findings of Shahzad et al. (2018) and Ahmad et al. (2009) who concluded that low concentrations of nickel led to improved and stimulated seed germination, seedling growth and improvement in fresh and dry weights of seeds. In the means of flowering and fruiting, our results revealed that there is a negative effect of different concentrations of nickel on flowers and fruits, as the toxicity of nickel increases at a concentration of $300 \mathrm{mg} / \mathrm{kg}$ of soil compared with the control. These results are consistent with Hussain et al. (2013) who reported that the toxicity of nickel affects the activity of many morphological characteristics. At the molecular level, our ISSR molecular marker did not reveal any polymorphism neither between treatments of nickel (100, 200, and $300 \mathrm{mg} / \mathrm{kg}$ of soil) on Vigna sinensis nor with the control and all bands seem monomorphic. These finding is in contrast with other studies that used RAPD and ISSR molecular markers and showed genotoxicity of heavy metals on plants (Al-Qurainy, 2009, 2010; Taheri et al., 2013). 


\section{Conclusion}

In the current study, the effect of various concentrations of nickel $(100,200$, and $300 \mathrm{mg} \mathrm{Ni}{ }^{2+} / \mathrm{kg}$ soil) has been investigated to identify their effects on Vigna sinensis. The results revealed the negative effects of nickel on the concentrations of mineral elements, chlorophyll a, reducing, non-reducing and total sugar content. Furthermore, the activity of studied enzymes (APX, GPX, CAT, SOD) decreased significantly. Moreover, the negative effects of nickel concentrations on the root, stem, leaves, seeds, flowers and fruits were obvious. On a molecular level, the ISSR markers could not detect any polymorphism, indicating no toxic effect of nickel on the DNA at the studied concentrations. It is obvious that the nickel has a toxic effect on Vigna sinensis at the physiological and morphological levels. The conduction of investigations on the effects of nickel on a molecular level using more molecular markers is highly recommended.

\section{REFERENCES}

[1] Aebi, H. (1984): Catalase in vitro. - Methods in Enzymology (Elsevier) 105:121-126. doi: https://doi.org/10.1016/S0076-6879(84)05016-3

[2] Ahmad, M. S. A., Hussain, M., Ashraf, M., Ahmad, R., Ashraf, M. Y. (2009): Effect of nickel on seed germinability of some elite sunflower (Helianthus annuus L.) cultivars. Pak J Bot 41: 1871-82.

[3] Al-Qurainy, F. (2009): Toxicity of heavy metals and their molecular detection on Phaseolus vulgaris (L.). - Australian Journal of Basic and Applied Sciences 3: 3025-35.

[4] Al-Qurainy, F. (2010): Application of inter simple sequence repeat (ISSR marker) to detect genotoxic effect of heavy metals on Eruca sativa (L.). - African Journal of Biotechnology 9(4).

[5] Allen, S. E., Grimshaw, H. M., Parkinson, J. A., Quarmby, C. (1974): Chemical analysis of ecological materials. - Blackwell Scientific Publications.

[6] Allen, S., Grimshaw, H., Parkinson, J., Quarmby, C. (1989): Organic constituents. - In: Chemical Analysis of Ecological Material. Blackwell Scientific Publications, Oxford, pp. 160-200.

[7] Asada, K. (1984): Chloroplasts: Formation of active oxygen and its scavenging. - In: Methods in enzymology. Elsevier, pp. 422-9.

[8] Asagba, S., Apiamu, A., Enokpe, F. (2019): Effects of nickel toxicity on the indices of germination and $\mathrm{Ca}^{2+}$ ATPase activity in cowpea plant (Vigna unguiculata). - Journal of Applied Sciences and Environmental Management 23: 1147-52.

[9] Ashraf, M. Y., Sadiq, R., Hussain, M., Ashraf, M., Ahmad, M. S. A. (2011): Toxic effect of nickel (Ni) on growth and metabolism in germinating seeds of sunflower (Helianthus annuus L.). - Biological trace element research 143: 1695-703.

[10] Bradford, M. M. (1976): A rapid and sensitive method for the quantification of microgram quantities of protein utilizing the principle of protein-dye binding. - Anal Biochem. 72: 248-54.

[11] Dovgalyuk, A., Kalinyak, T., Blume, Y. B., Glazko, V., Zwierzchowski, L., Oblap, R., Tarasyuk, S., Korsshikov, I., Bychkov, S., Klymchuk, D. (2001): Cytogenetic effects of toxic metal salts on apical meristem cells of Allium cepa L. seeding roots. - Tsitol. Genet 35: 3-10.

[12] Egley, G., Paul, R., Vaughn, K., Duke, S. (1983): Role of peroxidase in the development of water-impermeable seed coats in Sida spinosa L. - Planta 157: 224-32.

[13] Ewais, E. (1997): Effects of cadmium, nickel and lead on growth, chlorophyll content and proteins of weeds. - Biologia plantarum 39: 403-10. 
[14] Giannopolitis, C. N., Ries, S. K. (1977): Superoxide dismutases: I. Occurrence in higher plants. - Plant physiology 59: 309-14.

[15] Gjorgieva, D., Panovska, T. K., Ruskovska, T., Bačeva, K., Stafilov, T. (2013): Mineral nutrient imbalance, total antioxidants level and DNA damage in common bean (Phaseolus vulgaris L.) exposed to heavy metals. - Physiology and Molecular Biology of Plants 19: 499-507.

[16] Granito, M., Torres, A., Frías, J., Guerra, M., Vidal-Valverde, C. (2005): Influence of fermentation on the nutritional value of two varieties of Vigna sinensis. - European Food Research and Technology 220: 176-81.

[17] Harasim, P., Filipek, T. (2015): Nickel in the environment. - Journal of Elementology 20(2): 525-534.

[18] Hedge, J., Hofreiter, B., Whistler, R. (1962): Carbohydrate chemistry. - Academic Press, New York.

[19] Hussain, M. B., Ali, S., Azam, A., Hina, S., Farooq, M. A., Ali, B., Bharwana, S. A., Gill, M. B. (2013): Morphological, physiological and biochemical responses of plants to nickel stress: A review. - African Journal of Agricultural Research 8: 1596-602.

[20] Jagetiya, B., Bhatt, K. (2007): Relative toxicity of various nickel species on seed germination and early seedling growth of Vigna unguiculata L. - Asian J Bio Sci 2: 11-7.

[21] Jones Jr, J. B., Wolf, B., Mills, H. A. (1991): Plant analysis handbook. A practical sampling, preparation, analysis, and interpretation guide. - Micro-Macro Publishing, Inc.

[22] Kaveriammal, S., Subramani, A. (2013): Toxic effect of Nickel Chloride $\left(\mathrm{NiCl}_{2}\right)$ on the growth behavior and biochemical constituent of groundnut seedling (Arachis hypogeaea L.). - International Journal of Research in Botany 3: 48-52.

[23] Khan, S., Qureshi, M. I., Alam, T., Abdin, M. (2007): Protocol for isolation of genomic DNA from dry and fresh roots of medicinal plants suitable for RAPD and restriction digestion. - African Journal of Biotechnology 6: 175.

[24] Kumar, H., Sharma, D., Kumar, V. (2011): Nickel-induced oxidative stress and role of antioxidant defence in Barley roots and leaves. - International Journal of Environmental Biology 2(3): 121-128.

[25] Li, H., Long, C., Zhou, J., Liu, J., Wu, X., Long, M. (2013): Rapid analysis of monosaccharides and oligo-saccharides in hydrolysates of lignocellulosic biomass by HPLC. Biotechnology letters 35: 1405-9.

[26] Llamas, A., Sanz, A. (2008): Organ-distinctive changes in respiration rates of rice plants under nickel stress. - Plant Growth Regulation 54: 63-9.

[27] Llamas, A., Ullrich, C. I., Sanz, A. (2008): $\mathrm{Ni}^{2+}$ toxicity in rice: Effect on membrane functionality and plant water content. - Plant Physiology and Biochemistry 46: 905-10.

[28] Ma, X.-F., Ross, K., Gustafson, J. (2001): Physical mapping of restriction fragment length polymorphism (RFLP) markers in homoeologous groups 1 and 3 chromosomes of wheat by in situ hybridization. - Genome 44: 401-12.

[29] Macnair, M. R. (1993): The genetics of metal tolerance in vascular plants. - New Phytologist 124: 541-59.

[30] Maheshwari, R., Dubey, R. (2009): Nickel-induced oxidative stress and the role of antioxidant defence in rice seedlings. - Plant Growth Regulation 59: 37-49.

[31] Metzner, H., Rau, H., Senger, H. (1965): Untersuchungen zur synchronisierbarkeit einzelner pigmentmangel-mutanten von Chlorella. - Planta 65: 186-94.

[32] Mujeeb, A., Iqbal, M. Z., Shafiq, M., Kabir, M. (2019): Effects of Nickel Toxicity on Seedling Growth, Photosynthetic Pigments, Carotenoids and Phenols Contents of Cowpea Vigna unguiculata (L.). - International Journal of Environment, Agriculture and Biotechnology 4(2).

[33] Murphy, J., Riley, J. P. (1962): A modified single solution method for the determination of phosphate in natural waters. - Analytica chimica acta 27: 31-6. 
[34] Nguyen, V., Burow, M., Nguyen, H., Le, B., Le, T., Paterson, A. (2001): Molecular mapping of genes conferring aluminum tolerance in rice (Oryza sativa L.). - Theoretical and Applied Genetics 102: 1002-10.

[35] Panda, B. B., Panda, K. K. (2002): Genotoxicity and mutagenicity of metals in plants. - In: Physiology and biochemistry of metal toxicity and tolerance in plants. Springer, pp. 395414.

[36] Piccini, D., Malavolta, E. (1992): Effect of nickel on two common bean cultivars. - Journal of Plant Nutrition 15: 2343-50.

[37] Rathor, G., Chopra, N., Adhikari, T. (2014): Effect of variation in Nickel concentration on Growth of Maize plant: A comparative over view for Pot and Hoagland culture. - Research Journal of Chemical Sciences 4(10): 30-32.

[38] Sabir, M., Ghafoor, A., Zia-Ur-Rehman, M., Ahmad, H. R., Aziz, T. (2011): Growth and metal ionic composition of Zea mays as affected by nickel supplementation in the nutrient solution. - International Journal of Agriculture and Biology 13(2).

[39] Sarkar, T., Anand, K. V., Reddy, M. P. (2010): Effect of nickel on regeneration in Jatropha curcas $\mathrm{L}$. and assessment of genotoxicity using RAPD markers. - Biometals 23: 1149-58.

[40] SAS. (2014): SAS 9.4 Output delivery system: User's guide. - SAS Institute.

[41] Shahzad, B., Tanveer, M., Rehman, A., Cheema, S. A., Fahad, S., Rehman, S., Sharma, A. (2018): Nickel; whether toxic or essential for plants and environment-A review. - Plant Physiology and Biochemistry 132: 641-51.

[42] Singh, K., Pandey, S. (2011): Effect of nickel-stresses on uptake, pigments and antioxidative responses of water lettuce, Pistia stratiotes L. - Journal of environmental biology 32: 391.

[43] Sinha, S., Gupta, A. K. (2005): Translocation of metals from fly ash amended soil in the plant of Sesbania cannabina L. Ritz: effect on antioxidants. - Chemosphere 61: 1204-14.

[44] Stanisavljević, N., Savić, J., Jovanović, Ž., Miljuš-Djukić, J., Radović, S., Vinterhalter, D., Vinterhalter, B. (2012): Antioxidative-related enzyme activity in Alyssum markgrafii shoot cultures as affected by nickel level. - Acta physiologiae plantarum 34: 1997-2006.

[45] Stell, R., Torrie, J., Dickey, D. (1980): Principles and procedures of statistics: a biometrical approach. - New York: MacGraw-Hill.

[46] Taheri, S., Abdullah, T. L., Abdullah, N. A. P., Ahmad, Z. (2013): Use of intersimple sequence repeat assay for detection of DNA polymorphism induced by gamma rays in Curcuma alismatifolia. - HortScience 48: 1346-51.

[47] Yadav, R., Aery, N. (2001): Influence of different concentrations of nickel on some biometric characters in cowpea (Vigna sinensis L.). - Progressive Agriculture 1: 1-4.

[48] Yang, X., Baligar, V., Martens, D., Clark, R. (1996): Plant tolerance to nickel toxicity: II Nickel effects on influx and transport of mineral nutrients in four plant species. - Journal of Plant Nutrition 19: 265-79.

[49] Zietkiewicz, E., Rafalski, A., Labuda, D. (1994): Genome fingerprinting by simple sequence repeat (SSR)-anchored polymerase chain reaction amplification. - Genomics 20: 176-83. 